\title{
市販 $\mathrm{H}_{\mathrm{R}} \mathrm{C}$ カサ基凖片のばらつきについで
}

山城貞 男** 植 村 幸 生** 石 橋 徹***

\section{1. まえがき}

本報は“市販 $\mathrm{HRC}$ 硬さ基準片のばらつきが，JIS 飞規定する 0.5 以上あつて, 平均值を出す場合 5 点の 測定では足りないという工場現場の声を聞くので，そ の原因がはをして基準片にあるのか，試験機にあるの か，あるいはをを測定者淿あるのか調へ，その原因の 大半は基準片以外淿あるととを指摘しをものである。

\section{2. ばらつきの原因およびその程度}

測定值がげらつく原因として, 第1表に示す系統が 大要として考兊られる。乙れ以外飞振動や衝撃などの 外的影響もある。 HR を測定する場合には，乙れらの

第 1 表 $H_{R}$ のばらつきの原因

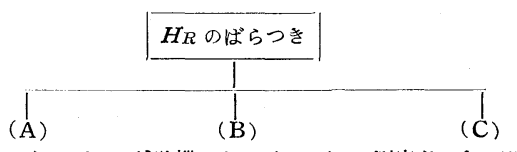

試料のばらつき 試験機によるばらつき＼cjkstart測定者によるばらつき

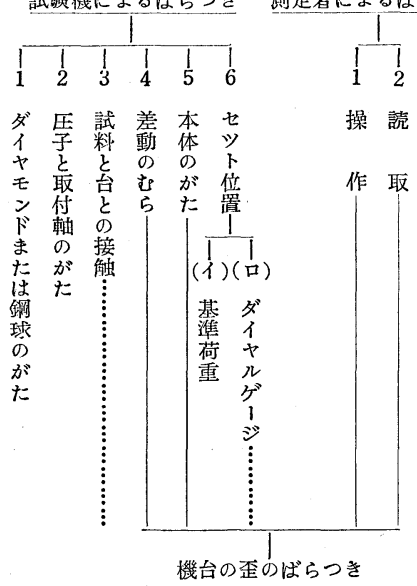

諸原因によるばらつきが全部重畳して出てきて，個及 飞取り出して吟味するとこができるのは，(B，6，口) のダイヤルダージだけである。したがつて, 同一基準 片飞対して測定者, 試験機を組合わせて, それぞれの ばらつをの程度を調べ，それから和の叔ののばらつを

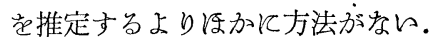

\section{1 機台の歪のばらつきと $\mathrm{H}_{\mathrm{R}} \mathrm{C}$ のばらつきの関}

* 原稿受付 昭和 30 年 12 月 5 日 材料試跧協会第 4 期秋期講演大 会 $($ 昭 $30 \cdot 11 \cdot 26)$ にて講演

*** 正員 大阪工業技衔竐験所

:
係 ことでらら機台の歪とは, JISB 7726 ロックウ エル硬さ試験機の 4. 指示装置の検査のうち 4. 1 亿 示されているととである.すなわち圧子を取りはすし た圧子取付軸をもつて, 機台を $150 \mathrm{~kg}$.で押圧すると き, 初めのセット位置と再び基準荷重にもどしたとき の指針の差をんう.

との機台の歪のばらつをを調べるととは, 試料のば らつきが入らずまた，簡単にでをて，HR のばらつ きの原因の究明に役立つ. しかし, 乙れ第1表に示 すように，(B 3〜6)秋よび(C)のばらつをの原因を含 んで拈り，一概にはいえない，しかし，機台の歪のば らつきの大きい試験機で測定すれば, その測定值は当 然大きくばらつくと考えられる。

第 1 図は 3 種類の同一基準片を, 同一測定者が 5 台 の試験機のおのおのにつ々て $\mathrm{HRC}$ を測定し, 機台の

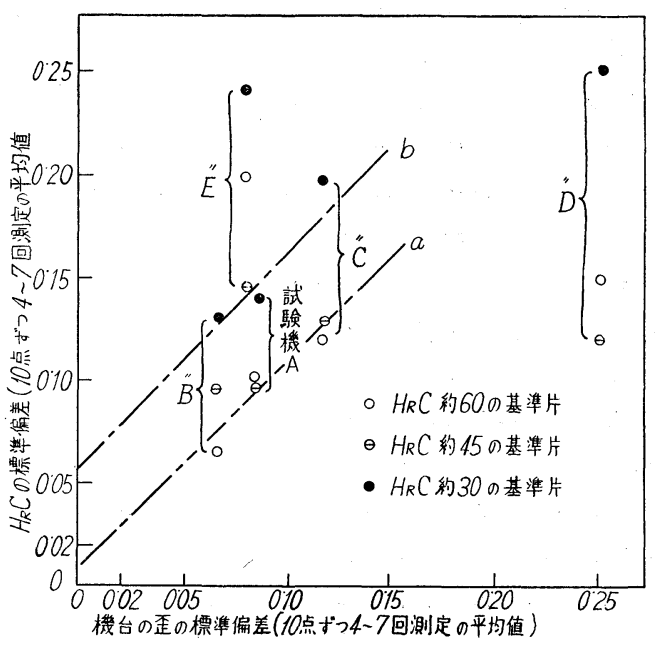

第 1 図 試験機による機台の歪の標準偏差と $\mathrm{HRC}$ の標準偏差

歪のばらつをと $\mathrm{HRC}$ のばらつきの関係を調べを結果 で, 10点ずつ 4〜7 回測定し, 各回の標準偏差の平均 值をとつたとの10点の標準偏差も各回どとにばらつく し試験機の数が少ないので，はつきりしたととはいえ ないが, だらたい次のように思われる。

*1）この資料は荷重継統㭙間と HRCの関係を調ぶた結果より転用 した. 
試験機 $\mathrm{A}, \mathrm{B}, \mathrm{C}$ Kつレてみると， 機台の歪の標準偏差と $\mathrm{HRC}$ の標準 偏差とがだらそに直線関係にある。 機台の歪のばらつきがそのまま $\mathrm{HRC}$ のばらつきと重㽡するものとすれば， $\mathrm{HRC}$ 約 60 の○印基準片と同じく, 約 45 のӨ印基準片の測定結果より, 横軸飞対して 45 度の傾斜を もつ直 線 $a$, 执よび同様にして $\mathrm{HRC}$ 約 30 の印基準片から直線 $b$ とが得られ る.もし，機台の歪のばらつをがな

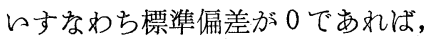
○印, 印では $\mathrm{HRC}$ の標準偏差は 約 0.01 で，印では 0.06 である。 こころみに，10点測定して 9 点が 同じ值で，他の 1 点だけが 0.1 異な れば標準偏差は約 0.03 であり， 8 点が同じ值で他の 2 点が 0.1 だけ異 なれば標準偏差は約 0.05 である。
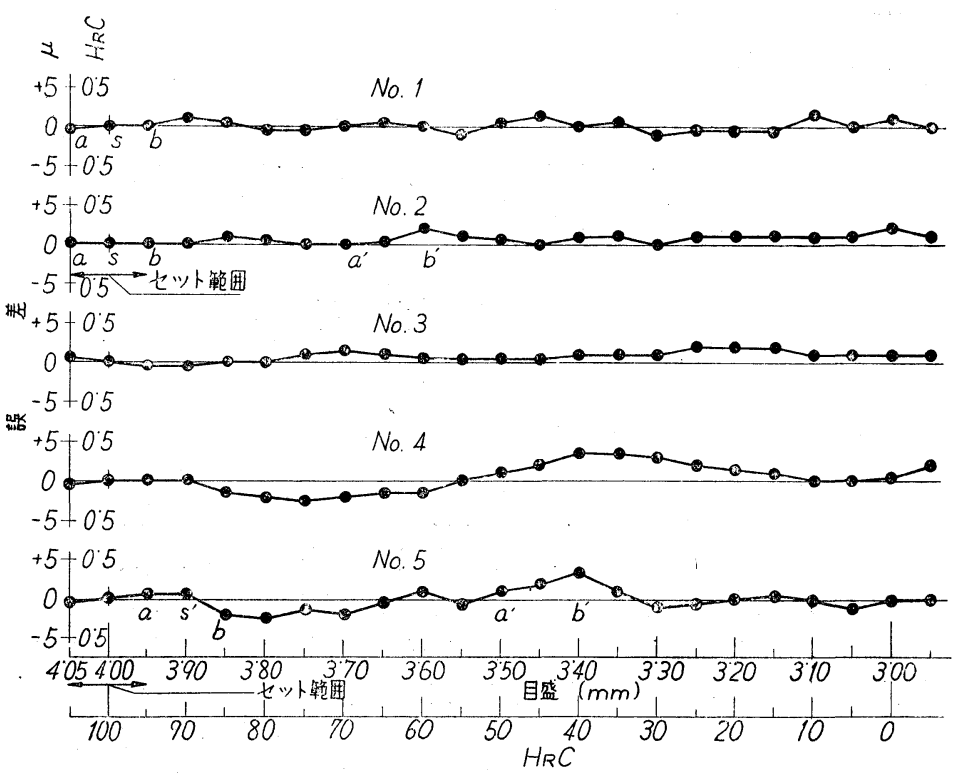

第 2 図 ダイヤルゲージの精度

それゆえもし機台の歪のばらつきがない試験機で

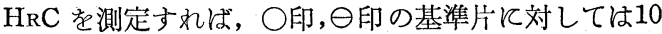
点測定で，9点以上が同じ值になり，他の 1 点以下が $0 \cdot 1$ 異なる值を示し，また， の印の基準片飞対しては 10 点のうち 8 点が同じ值で, 他の 2 点が 0.1 異なつを 值を示すととになる．機台の歪のばらつきのない試験 機は理想的な試験機であつて，現在ある試験機では， 後述するように，読取誤差によるね゙らつきのみでも標 準偏差が約 0.07 0.12 ある. との読取誤差による標 準偏差が試験機 $\mathrm{B}$ の機台の丕や○印基準片の $\mathrm{HRC}$ の 測定值の標準偏差の約 0.07 と一致するととろから， 試験機 $\mathrm{B}$ 以上ばらつをの少ない試験機は，普通市販の 試験機では考えられない。

しかし，以上のととは機台の歪のばらつきが，その まま $\mathrm{HRC}$ のばらつきに重畳すると仮定し号場合で， 実際は試験機 D，Eが示すよう飞簡単ではない。試験 機Dは機台の歪のばらつきが非常に大きいにもかかわ

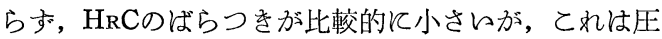
子取付軸の端面と載物台の面とが平行になつていなか そそつめ，機台の歪のばらつきが大きく出をと考允ら れる. 試験機 $\mathrm{E}$ は機台の歪のばらつきがささいにもか かわらず， HRC のばらつきが大きいが，乙れは後述 する。（B．6，口）飞よる原因と思う。

\section{2 セット位置のばらつきによる $H_{R}$ のばらつ}

2. 2.1 基準荷重を与允るためスプリング を使用している試験機では，七ット位置により基準荷

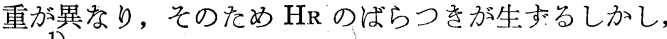
吉沢の論文によれば基準荷重に士2.5\%の誤差のそめ 生和る $\mathrm{HRC}$ の誤差は， $\mathrm{HRC} 80,20,0$ 亿対してそ

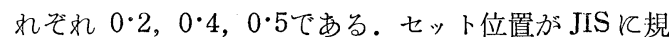
定する真上方向飞対して左右 5 目盛以内であれば，ば ね常数を $0.5 \mathrm{~kg} / \mathrm{mm}$ として, とれによる基準荷重の ばらつまは $\pm 5 \mathrm{~g}$ 以内である。したがつて， $\mathrm{HRC} の$ ばらつをは $\pm 0 \cdot 01$ 以下となり無視できる。

2. 2. 2. ダイヤルゲージは場所により誤差が異な り，したがつて，セット位置が異なると圧子がたとえ 同じ深さ圧入しても，ダイヤルダージの指針は異なつ そ値を示す。第 2 図は某製作所より提供されそダイヤ ルゲージの精度で, No. 5 は社内規格で不合格になつ たものである.ダイヤルゲーシ No.2 そつレて $\mathrm{HRC}_{\mathrm{R}}$ （HRB も同様）のセット位置によるばらつきにつ々て 述べよう. No.2 の点が真上方向であるとすれば，JIS で規定されるセット位置の範囲は左右 5 目盛, すなわ ち $a b$ の間である. 今, $\mathrm{HRC}_{\mathrm{R}} 65$ の基準片を測定した とし， $a$ 亿セットす机ば指針は $a^{\prime}$ を示し， $b$ Kセッ トすれば $b^{\prime}$ をでいをい示すととになる。 $a b$ 間保差 がなく $a^{\prime} b^{\prime}$ 間飞 $2 \mu$ の誤差があるから，七ット位置を $a b$ の籁囲飞とるととにより，ダイヤルゲージのみに よる $\mathrm{HRC}$ のばらつきは 0.2 亿なる。 $\mathrm{HRC} 70$ 以上まを は50以下では約 $0 \cdot 1 て ゙ あ る 。$ 最悪の場合として, 不合 格であつそ No.5.のダイヤルゲージが試験機て使用さ れ, ダイヤルゲージの真上方向飞 $\mathrm{S}^{\prime}$ 点がとられ, $\mathrm{HRC}$ 55 を測定すれば， $a b$ のセット籁囲により HR 単位で 最大約 0.5 のばらつきが生稀るととなる。とのとと は使用場所により，ダイヤルゲージによるばらつきが 異孛るととを示して和り, 第 1 図の○印, $\ominus$ 印の基準 沜の゙らつきが試験機により逆になつているのも, と の点飞起因していると考完られる。 
また図と示す Nos.1〜 5 のダイヤルゲージが S 点で 取り付けられるならば, 前述の機台の歪のうちダイヤ ルダージルよるばらつをは, No.2 を除き全試験機に

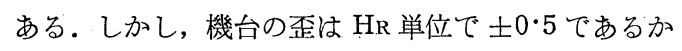
ら, このばらつきは 0.01 程度で無視できて,ダイヤル ゲージの誤差は機台の歪のばらつをには出てとない， とのととから, 第 1 図の試験機 $\mathrm{E}$ は機台の歪のばらつ きが小さいにもかかわらず, $\mathrm{HRC}$ の值がげらついて レるのは, この試験機のダイヤルゲージが悪いためと 想像される。

ばらつをを小さくしょうとするならば，七ット䉓囲 を JIS の左右 5 目盛以下飞するよう飞努め, ダイヤル ゲージの䛊差も場所氏より極端な变化がないととが望 ましく, 特にNo. 5 のダイヤルゲージの $\mathrm{S}^{\prime}$ 点のような 所が真上方向にセットされると, $\mathrm{H}_{\mathrm{R}}$ のばらつきは全 籁围婂わてつて大きくなる。

2.3 測定者によるばらつき 第 2 表は同一基準 片に対して測定者, 試験機をかえて, ばらつをを調べ そ結果である。測定者 I, II, III は, 操作によりばら

第 2 表 同一基準片に対して試駼機叔よび 測定者によるばらつを

\begin{tabular}{|c|c|c|c|c|c|c|}
\hline 試 験 機 & A & A & A & B & $\mathrm{F}$ & $\mathrm{F}$ \\
\hline \multirow[t]{5}{*}{ 測 定 者 } & I & II & III & $I$ & I & IV \\
\hline & $63 \cdot 4$ & $63 \cdot 5$ & $63 \cdot 3$ & $63 \cdot 4$ & $63 \cdot 5$ & $63 \cdot 2$ \\
\hline & $\cdot 7$ & $\cdot 6$ & $\cdot 4$ & $\cdot 5$ & $\cdot 6$ & $\cdot 4$ \\
\hline & $\cdot 5$ & $\cdot 5$ & $\cdot 3$ & .5 & $\cdot 5$ & $\cdot 6$ \\
\hline & $\cdot 3$ & $\cdot 5$ & $\cdot 2$ & $\cdot 5$ & $\cdot 5$ & $\cdot 5$ \\
\hline \multirow[t]{5}{*}{ 測 } & $\cdot 4$ & $\cdot 7$ & $\cdot 2$ & $\cdot 6$ & $\cdot 7$ & $\cdot 7$ \\
\hline & $\cdot 6$ & $\cdot 4$ & $\cdot 2$ & $\cdot 6$ & 5 & $\cdot 2$ \\
\hline & -5 & $\cdot 6$ & $\cdot 3$ & $\cdot 5$ & $\cdot 5$ & $\cdot 8$ \\
\hline & $\cdot 5$ & $\cdot 8$ & $62 \cdot 9$ & $\cdot 5$ & $\cdot 5$ & $\cdot 9$ \\
\hline & $\cdot 4$ & $\cdot 5$ & $63 \cdot 0$ & $\cdot 5$ & $\cdot 6$ & $\cdot 5$ \\
\hline \multirow[t]{5}{*}{ 定 } & $\cdot 7$ & $\cdot 3$ & $\cdot 2$ & $\cdot 6$ & $\cdot 6$ & $\cdot 4$ \\
\hline & $\cdot 4$ & $\cdot 5$ & $\cdot 1$ & $\cdot 4$ & $\cdot 5$ & $\cdot 2$ \\
\hline & $\cdot 5$ & $\cdot 7$ & $\cdot 2$ & $\cdot 6$ & $\cdot 5$ & $\cdot 5$ \\
\hline & $\cdot 6$ & $\cdot 4$ & $\cdot 4$ & $\cdot 5$ & $\cdot 6$ & $\cdot 7$ \\
\hline & $\cdot 6$ & $\cdot 6$ & $\cdot 2$ & $\cdot 6$ & $\cdot 7$ & $\cdot 1$ \\
\hline \multirow[t]{6}{*}{ 值 } & $\cdot 7$ & $\cdot 5$ & $\cdot 1$ & $\cdot 5$ & $\cdot 7$ & $\cdot 3$ \\
\hline & $\cdot 5$ & $\cdot 5$ & $\cdot 0$ & $\cdot 4$ & $\cdot 8$ & $\cdot 6$ \\
\hline & $\cdot 3$ & $\cdot 6$ & $\cdot 3$ & $\cdot 5$ & $\cdot 7$ & $\cdot 8$ \\
\hline & $\cdot 6$ & $\cdot 8$ & $\cdot 0$ & $\cdot 6$ & $\cdot 6$ & $\cdot 8$ \\
\hline & $\cdot 5$ & $\cdot 8$ & $\cdot 3$ & $\cdot 6$ & $\cdot 6$ & $\cdot 2$ \\
\hline & $\cdot 5$ & $\cdot 4$ & $\cdot 0$ & $\cdot 6$ & $\cdot 6$ & $\cdot 4$ \\
\hline 平均值 & $63 \cdot 5_{1}$ & $63 \cdot 5_{5}$ & $63 \cdot 1_{8}$ & $63 \cdot 5_{3}$ & $63 \cdot 59$ & $63 \cdot 49$ \\
\hline $\begin{array}{l}\text { 最大值と最 } \\
\text { 小值の差 }\end{array}$ & 0.4 & 0.5 & 0.5 & 0.2 & $0 \cdot 3$ & 0.8 \\
\hline 標潐偏差 & $0 \cdot 12$ & $0 \cdot 14$ & $0 \cdot 15$ & 0.07 & 0.09 & 0.25 \\
\hline
\end{tabular}

つきが生ずるとと起頭に置き，1点1点の測定にあ そつて慎重に同じ操作を繰返しを結果で，少々の羑は あるが、ばらつをの程度はだらたい一定である。試験 機 $\mathrm{F}$ 、基準片でも非常にばらつを，5点測定で最大值 と最小值の差が, 時々 1 以上もあると話があつた工場 の試験機であつて, 測定者 IV は実際て工場で測定し ている人である. 同じ陚験機 $\mathrm{F}$ の測定者 I てよる結果

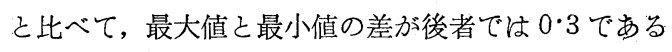
飞もかかわらず, 前者は0.8で, 明らかてばらつきの 原因の大半は測定者 $1 \mathrm{~V}$ の操作とあつて, 基準片, 試 駼機によるばらつをは少ない. 事実, 測定者 IV は未 熟であつて, セット位置にもつていくのに上下ハンド ルをををいてりして操作が円滑でなかつて。

2.4 読取誤差によるばらつきロックウェルで は読取䛊差が，セットする場合と最後に硬さ値を読み とる場合と 2 回あり, その組合せにより基準片和よび 試駼機にばらつきがないとしても, 硬さ值にばらつき が生ずるととになる、いま，乙の読取誤差が $\pm 0 \cdot 05$ まをは土0・エあるとし，それが仮第 3 表に示すよう 飞同じ確率で起これば, 最大值と最小值の差は 0.2 ま そは 0.4 となり，標準偏差は 0.07〜0.12 である。前 述の第 1 図や第 2 表の試験機 A，B，C の機台の歪や ○印, $\ominus$ 印基準片の $\mathrm{HRC}$ の標準偏差は 0.07〜0.12 で 西るから, 読取誤差による標準偏差 $0.07 \sim 0.12$ と一 致している.とのととから硬的基準片にはばらつをが なく, あるとしても読取誤差によるばらつきと同程度 である。したがつて, 読取䛊差によるげらつきも大き く，乙れをでをる限り小さくするためにはダイヤルゲ 一ジの指針を機械的強度の許す限り細かくするととが 望まし々. 第 2 表の試験機Bのばらうきが小さく標準 偏差が 0.07 であるのは, 指針の細からととが影響し, 読取誤差を \pm 0.05 程度に和さええたと想像される。

第 3 表 読取䛊差によるばらつき

\begin{tabular}{|c|c|c|c|c|c|}
\hline \multicolumn{3}{|c|}{ \pm 0.05 の場合 } & \multicolumn{3}{|c|}{ \pm 0.1 の場合 } \\
\hline セット誤差| & $\begin{array}{l}\text { 最後の } \\
\text { 娔取鎮差 } \\
\end{array}$ & 合 & セット愦差 & $\begin{array}{l}\text { 最後 } 0 \\
\text { 読取椇差 }\end{array}$ & 合 \\
\hline-0.05 & -0.05 & -0.1 & -0.1 & $-0 \cdot 1$ & -0.2 \\
\hline 0 & -0.05 & -0.1 & 0 & -0.1 & -0.1 \\
\hline-0.05 & 0 & 0 & -0.1 & 0 & -0.1 \\
\hline-0.05 & +0.05 & 0 & -0.1 & +0.1 & 0 \\
\hline 0 & 0 & 0 & 0 & 0 & 0 \\
\hline+0.05 & -0.05 & 0 & +0.1 & $-0 \cdot 1$ & 0 \\
\hline+0.05 & 0 & 0 & $+0 \cdot 1$ & 0 & $+0 \cdot 1$ \\
\hline 0 & +0.05 & +0.1 & 0 & +0.1 & +0.1 \\
\hline$+C \cdot 05$ & +0.05 & +0.1 & +0.1 & $+0 \cdot 1$ & $+0 \cdot 2$ \\
\hline \multicolumn{2}{|c|}{ 最大值と最小値の差 } & 0.2 & \multicolumn{2}{|c|}{ 最大值と最小值の曾 } & 0.4 \\
\hline 標 潐 & 偏 差 & 0.07 & 櫭 潐 & 偏 差 & $0 \cdot 12$ \\
\hline
\end{tabular}


2.5 その他はつきりした結果は得ていないが われわれの実験中にたとえ基準片の周囲に空打ちした 後であつても, 一番初めの測定值が 0.1 程度であるが 最小值を示す確率が多く，130例中 50 例を数えた。 しそうであ礼ば，（B3）などの原因と考えられる。（B 1，2）の原因は普通の場合はない. 負荷機構や指示機 構など差動部分の摩擦や荷重継続時間の影響は, それ ぞれ(B4)，(C1)のばらつきの原因になるが，乙れは 普通の連続操作中㒖少であると思う. また, 最後に基 準荷重にかえして硬さ值峞読みとるとき, 指針は弾性 回復のためいつたん大きくかえり,さらに弾性余効の そめに少しすつ硬い方に移動する。 0.1 程度の差は基 準荷重にかえしてからの読取時間により生するる。

たとえ，くぼみの間隔が JIS の規定するくぼみの直 径の 4 倍以上あつても, 基準片に打つたくぼみの総数 が比較的に多くなると, ばらつきが大きくなるようで ある. この点に関しては単に経験によるものであつて, 詳細には調べていない.

\section{3. 結 論}

（1）市販の $\mathrm{HRC}$ 基準片の硬い方はばらつきがな レ、たとえあつたとしても, 読取誤差に起因するばら つをと同程度か, それ以下である. 軟々方の基準片の ばらつをは読取誤差によるばらつをを 001 程度越え る.との土0.1のばらつをも試験機や測定者に起因す るものかもしれない. この点をさらに明確にするには 空気マイクロメータなどの高感度の測定器在用いなけ ればならない。

（2）すでにあるくばみの数が少ないときに，5点 の測定で最大值と最小值の差が 0.5 を越えるととは, 試験機が悪々のか, 測定者の操作が悪らのかいずれか である。

（3）機台の歪のばらつをを調べるととは意義があ る、このばらつきが小さい試験機は一応安定している といえる．た艺し，機台の歪のばらつをを調べてもダ イヤルゲージの良否は判定できない. それゆえ試験機 を購入するとをは,ダイヤルゲージの精度表をつけて
もららか, セット位置をたとえば右10目盛附近にした とき, 真上方向附近のとき, 左10目盛にしたときの, の $\mathrm{HRC}$ 值を比較するとよい.

以上は国内某社製の基準片についてであるが, 他社 も同様と想像する.

ばらつきがないとの極論に対し, ビッカースで測定 すれば，明らかに基準片にかたさのばらつきが認めら れると反ばくできる。しかし，ビッカースはロックウ ェルに比して, くばみが小さく微小部分を対象にして らる。またビッカースも読取誤差によるばらつきがあ る.ただ 1 箇のビッカースのくぼみを微小硬度計の計 測影微鏡で, 10回すつ 4 人て測定したとてろ, 最大值 と最小值の差が対角線の長さで最小の人でさえ $0.5 \mu$ あつたが, 理論的にもこれ以上は無理であろう。この $0.5 \mu$ JIS の希望する対角線の長さ 200〜 $500 \mu$ の約 $0.1 \sim 0.25 \%$ で，したがつて $\mathrm{Hv}$ で $0.2 \sim 0.5 \%$ ある から，乙れを $\mathrm{HRC}$ に換算すれば $0.1 〜 0.3$ のばらつ きになる.普通, 対角線の読取誤差は $1 \mu$ と考えるべ きであるから， HRC K換算すれば $0.2 〜 0.6$ の菭らつ きになる。もつとも $150 \mathrm{~kg}$ のうな大荷重でビッカー ス硬さ試験を行えば, 読取誤差の影響が少なくなり, ばらつきの有無が明瞭になる。

試験機の操作を円滑に行らことは, 硬さ値を正確に 出すとととともに，ばらつをを小さくする．操作方法 も統一する必要がある。

$\mathrm{HRB}$ の基準片は改善さるべを点を多く含んでいる が, $\mathrm{HRC}$ の基準片は絶体值和よび経年変化の問題を 残しても, ばらつきの点では一応現状で満足できるも のと思われる。したがつて筆者らはロックウェル試験 機执よど取扱い方を改善し，再び問題が基準片に移行 するととを望む。

終りに, 本実験に御協力レただをむした工場の各位 に厚く御礼申上げます。

注:-

1）吉沢武男 機械学会諭交集 14巻, 46 号, p. 41（昭23） 